\title{
Topônimos angolanos de origem bantu: princípios para harmonização gráfica ${ }^{1}$
}

\section{Angolan Toponyms from Bantu Languages: Criteria for Spell Harmonization}

\author{
Hélder Pande Alexandre* \\ *Instituto Superior de Ciências da Comunicação, Luanda / Angola \\ helderpande@hotmail.com \\ https://orcid.org/0000-0001-5916-7401
}

\begin{abstract}
RESUMO: O presente trabalho procurou apresentar determinados critérios pelos quais se deve reger o registo dos topônimos de origem bantu na língua portuguesa, à luz do fenômeno do empréstimo linguístico. Entende-se que os topônimos são unidades lexicais como as demais, pelo que, sempre que possível, devem obedecer às regras de grafia da língua-alvo. Para isso, desenvolveu-se uma pesquisa documental e de campo, recorrendo-se à técnica de focus group para validação da informação recolhida. Do ponto de vista da escrita, os dados recolhidos demonstram que há divergências na forma gráfica dos topônimos de origem bantu. Desse modo, propuseram-se determinados princípios para a sua uniformização, evitando-se as múltiplas grafias que se observam.
\end{abstract}

PALAVRAS-CHAVE: contato linguístico; harmonização gráfica; interferência linguística; topônimos de origem bantu.

\begin{abstract}
This study presents some criteria to spell Bantu toponyms in Brazilian Portuguese following the language lending phenomenon. We understand that toponyms are lexical and therefore they should obey the target language spelling rules as much as possible. To achieve this purpose, we conducted a documentary and field research using focus groups to validate the collected information. From a spelling point of view, the collected data show that there are some divergences in the writing form of Bantu toponyms. Thus, we proposed some criteria for their standardization, avoiding the multiple spellings observed.
\end{abstract}

KEYWORDS: linguistic contact; linguistic interference; spell harmonization; toponyms from Bantu origin.

\footnotetext{
${ }^{1}$ Artigo extraído e atualizado da dissertação de mestrado em Terminologia e Gestão de Informação de Especialidade apresentada à Faculdade de Ciências Sociais e Humanas da Universidade Nova de Lisboa, sob título Proposta de harmonização gráfica da toponímia de Angola: o caso do município de Malanje, orientada pela doutora Maria Teresa Rijo da Fonseca Lino.
} 


\section{Introdução}

A escrita dos topônimos angolanos de origem bantu tem sido alvo de muitos debates nos últimos cinco anos. Essas discussões têm envolvido desde especialistas de vários domínios aos leigos. Entre os especialistas, destacam-se sobretudo juristas, sociólogos, antropólogos e linguistas orientados para as línguas africanas (doravante LA). A ideia reinante é a de que os nomes próprios que têm origem nas LA devem ser escritos segundo as normas ortográficas dessas, obedecendo ao alfabeto aprovado pela Resolução no 3/1987 (ANGOLA, 1987), o que implicaria o respeito à sua autonomia relativamente à língua portuguesa (doravante LP). Considerase, na verdade, uma reivindicação justa que as LA não sejam subordinadas à LP, como aconteceu durante o domínio colonial português, tendo como apogeu o conhecido Decreto n ${ }^{\circ} 77 / 1921$ de 17 de dezembro, do então alto comissário de Angola, Norton de Matos. Todavia, entende-se, também, que a autonomização das LA de Angola não deve significar a sobreposição dessas em relação à LP, mas a assunção de medidas de políticas que permitam: 1) o seu estudo; 2) a sua inserção no sistema de ensino, sobretudo no ensino primário para crianças que as têm como língua materna; e 3) o seu uso em espaços públicos sem o menor preconceito.

Relativamente à escrita dos nomes oriundos das LA na LP, é necessário nunca se perder de vista que estamos perante o fenômeno de contato de línguas e, especificamente, de empréstimo linguístico, havendo unidades lexicais de uma língua que passam para a outra. Assim sendo, compreendese com a maior naturalidade que os antropónimos respeitem a grafia de origem, sendo, por isso, imprópria a sua adaptação à LP, salvo se já estiverem perfeitamente integrados ao léxico português. É o caso, por exemplo, do anglicismo Nelson, atualmente registado como Nélson, sendo ambas as formas aceitas na LP. No caso vertente das LA, parece razoável que se escreva Ngola Kilwanji em vez de N'gola Quiluanje, pois trata-se de um antropónimo.

Dado que a toponímia configura um subdomínio da onomástica, esta abordagem ancora-se, entre outros autores, em Vasconcellos (1931), Ullmann (1977) e Dick (2007). Para a abordagem do fenômeno de contato linguístico, este trabalho sustenta-se em Mateus et al (1990), Vilela (1994), Costa (2006), Azeredo (2012), entre outros.

Este estudo pretende contribuir para uma harmonização da representação gráfica, de modo que sejam evitadas as múltiplas grafias atualmente existentes. 


\section{Referencial teórico}

\subsection{Lexicologia, onomástica e toponímia}

O léxico de uma língua é composto por unidades lexicais que têm importância referencial - verbos, substantivos e adjetivos - ou funcional conjunções, preposições, artigos. Por assim ser, Coseriu (1979, p. 17) defende que "nem tudo o que é uma 'palavra' pertence ao léxico como objecto da lexemática, uma vez que há palavras ('categoremas', 'instrumentos') que não têm qualquer significado lexical". Para o presente trabalho importam sobretudo as unidades lexicais com valor referencial, especificamente os nomes e as palavras substantivadas. $\mathrm{Na}$ classe dos nomes, este trabalho interessa-se particularmente pelos nomes próprios, pois é à volta dessa classe de palavras que se desenvolve.

Com efeito, a lexicologia reserva à onomástica o estudo dos nomes próprios, incluindo-se os antropônimos (nomes de pessoas), os fitônimos (nomes de plantas), os zoônimos (nomes de animais) e os topônimos (nomes de lugares). A toponímia, por sua vez, dedica-se ao estudo dos nomes próprios dos lugares e acidentes geográficos.

Os nomes próprios possuem uma forte ligação com os entes que designam. Ullmann (1977, p. 149) sublinha que "os nomes desempenham nas relações humanas um papel tão importante que são frequentemente dotados de poderes mágicos e rodeados de complicadas superstições e tabus". Embora os nomes próprios obedeçam às mesmas regras da língua que os nomes comuns (VASCONCELLOS, 1931), "o conceito de nome próprio está assim profundamente arreigado na tradição, e, na vida diária, não temos dificuldade em reconhecer tais nomes e os distinguir dos substantivos comuns, escrevendo-os com maiúscula”. (ULLMANN, 1977, p. 151)

Esse autor apresenta cinco critérios para a distinção entre nomes próprios e nomes comuns, nomeadamente unicidade, identificação, designação contra conotação, som distintivo e critérios gramaticais. A unicidade está relacionada com o fato de um nome próprio significar um ser de forma individualizada. A identificação encara os nomes próprios como marca de identificação, distinguindo uma pessoa ou objeto de outros semelhantes. A designação contra conotação descreve os nomes próprios como estruturas designativas, diferentes dos nomes comuns que são vistos como estruturas conotativas (ULLMANN, 1977). O critério som distintivo 
revela "uma característica de todas as palavras (excepto no caso bastante especial dos homónimos)" (ULLMANN, 1977, p. 155), dado o fato de elas "terem uma configuração distintiva própria, que as diferencia de outros termos" (ULLMANN, 1977, p. 155). O último critério apresentado pelo autor diz respeito a determinadas especificidades gramaticais peculiares aos nomes próprios, sendo essas variáveis de uma língua para outra, como a pluralização dos nomes próprios que só acontece em casos especiais e a determinação do nome próprio através do artigo.

Face ao acima exposto, Ullmann sublinha que o critério identificação é o que parece ser mais útil, porque "[a] diferença essencial entre os substantivos comuns e os nomes próprios reside na sua função: os primeiros são unidades significativas, os segundos simples marcas de identificação" (ULLMANN, 1977, p. 160). Ao realçar o papel identificador dos nomes próprios, o autor evoca a ideia clássica de que o nome próprio é visto como "rótulo fixado numa pessoa ou numa coisa para a identificar, distinguindo-a de elementos similares" (ULLMANN, 1977, p. 153). Essa noção do nome como rótulo é rejeitada por Dick que, partindo dos conceitos gregos de onoma e logos, procura "estudar o nome como fato genérico, ao qual chamamos 'sistema onomástico', pelas relações que os nomes aí estabelecem, marcando todo o ordenamento gramatical e de significados" (2007, p. 145). Entende a autora que "isto é possível porque o nome não é apenas um rótulo ou etiqueta colada sobre o objeto". (DICK, 2007, p. 145)

Do grego topos (lugar) e onomas (nome), a Toponímia é entendida como o estudo da origem, evolução e significação dos topônimos. Há autores, contudo, que usam termos como Coronímia Nominativa, Nomenclatura Geográfica ou Geonímia para a análise da etimologia dos nomes dos lugares (SEEMANN, 2005, p. 211). Segundo constata Dick (2006, p. 98), "[a] Toponímia desenvolveu-se acompanhando um vocabulário geográfico de ocorrências, pois geográfico era o seu objeto de estudo (topos = lugar), na distribuição entre elementos físicos e antrópicos da paisagem, mas em relação intersemiótica".

Qualquer língua dispõe de diversos recursos de formação de palavras. Neste estudo de caso, daremos especial atenção aos empréstimos linguísticos, pois entende-se que se está a tratar de uma situação de contato de línguas - o Kimbundu e o Português. Nesse aspecto, centra-se sobretudo na interferência do Kimbundu na LP. 


\subsection{A Toponímia como objeto de estudo da lexicologia}

No âmbito do estudo da lexicologia, a toponímia pode ser vista como um recurso de enriquecimento e renovação do léxico, uma vez que, por intermédio da toponímia, o léxico da língua adquire novas palavras ou as que já existem ganham novos sentidos. Nessa perspectiva, os topônimos também podem ser alvos de estudo da neologia por ser essa especialmente vocacionada para dar conta dos neologismos.

Além dos topônimos propriamente ditos (que são nomes próprios), também contribuem para o enriquecimento do léxico da língua com os adjetivos gentílicos que são formados a partir deles, como angolano, de Angola, português, de Portugal ou brasileiro, de Brasil.

Desse modo, dado o número de topônimos existentes na língua, quer os de origem na língua portuguesa, quer os que são tomados como empréstimo de outras línguas, é bastante razoável que o estudo do léxico considere a toponímia como uma área que careça de uma abordagem especial, sobretudo pelo caráter multidisciplinar que a envolve.

Os estudos toponímicos de forma sistematizada, segundo Dick (1987), começaram em França, por volta do ano 1878, com Auguste Longnon na École Pratique de Haute Études e no Colégio de França, tendo como resultado a publicação póstuma, pelos seus alunos, da Les noms de lieu de la France, após 1912. Conforme ainda descreve Dick, após a morte de Longnon, Albert Dauzat deu sequência, em 1922, aos estudos onomásticos, tendo publicado Chronique de Toponymie.

Dos autores de língua portuguesa, destacam-se os trabalhos ligados à onomástica desenvolvidos por Vasconcellos, com realce para a obra Opusculos (1931). Dos vários autores brasileiros que se têm dedicado ao estudo da onomástica, em geral, e da toponímia, em particular, destaca-se naturalmente Dick, cujos trabalhos têm sido tomados como modelos nos estudos toponímicos, nomeadamente $A$ motivação toponímica e a realidade brasileira (1990), A motivação toponímica: princípios teóricos e modelos taxionômicos (1990), A dinâmica dos nomes na cidade de São Paulo: 1554-1897 (1996), entre outros.

De acordo com a Grande Enciclopédia Portuguesa e Brasileira (doravante GEPB), Vasconcellos divide o estudo dos topônimos em três partes, nomeadamente linguística toponímica, gramática toponímica e proveniência toponímica. A "linguística toponímica, em que se estudam os nomes de lugares classificados por línguas; gramática toponímica, em que se trata 
de modos de formação dos referidos nomes; proveniência toponímica, em que se encaram os topônimos segundo as causas que os originaram" (GRANDE..., 1968, p. 73). A essas três partes, acrescenta-se a geografia toponímica que, segundo a GEPB, tem a ver com a "distribuição de um topônimo, especialmente quando ele e seus derivados e flexões ocorrem em abundância através do território do País”. (GRANDE..., 1968, p. 82)

Em função da causa que dá origem ao topônimo, a toponímia tem sido classificada de uma determinada forma. Os aspectos paisagísticos, por exemplo, dão origem a diversos topônimos, nomeadamente aspectos relativos à fauna, flora, hidrografia, solos etc. A esse modelo de classificação, Dick dá o nome de sistema toponímico taxionômico. A respeito dessa classificação, a autora afirma o seguinte:

Definidos à maneira dos hiperônimos (termos redutores dos significados compreendidos nas expressões denominativas) ou arquilexemas, constituem-se em indicativos ou marcadores semântico-terminológicos; têm a finalidade de, por meio de uma nomenclatura específica (termo genérico motivador, indicativo do campo semêmico determinativo, seguido da expressão topônimo), transmitir os vínculos causais que justificam a criação dos nomes de lugares. (DICK, 2007, p. 142)

A autora apresenta um "Sistema Toponímico Taxionômico, estruturado em vinte e sete taxes explicativas ou categoremas toponímicos" (DICK, 2007, p. 142, grifo da autora). Esse "Sistema Toponímico Taxionômico" apresentado por Dick divide-se em dois grupos: onze taxes de topônimos de Natureza Física e dezasseis taxes de topônimos de Natureza Antropo-Cultural, como se apresentam nos Quadros 1 e 2.

QUADRO 1 - Classificação taxionômica dos topônimos de Natureza Física, segundo Dick

\begin{tabular}{|l|l|}
\hline \multicolumn{1}{|c|}{ Categoria } & \multicolumn{1}{c|}{ Descrição } \\
\hline Astrotopônimos & Topônimos relativos aos corpos celestes em geral \\
\hline Cardinotopônimos & Topônimos relativos às posições geográficas em geral \\
\hline Cromotopônimos & Topônimos relativos às escalas cromáticas \\
\hline Dimensiotopônimos & $\begin{array}{l}\text { Topônimos relativos às dimensões dos acidentes geográficos: extensão, } \\
\text { comprimento, largura, grossura, espessura, altura e profundidade }\end{array}$ \\
\hline
\end{tabular}




\begin{tabular}{|l|l|}
\hline Fitotopônimos & Topônimos relativos aos vegetais \\
\hline Geomorfotopônimos & $\begin{array}{l}\text { Topônimos relativos às formas topográficas: elevações, montanhas, } \\
\text { montes, morros, colina, depressões de terrenos, costa, cabo, angra, ilha, } \\
\text { porto }\end{array}$ \\
\hline Hidrotopônimos & Topônimos relativos a acidentes hidrográficos: água, rio, córrego, foz \\
\hline Litotopônimos & Topônimos relativos aos minerais e à constituição do solo \\
\hline Meteorotopônimos & Topônimos relativos aos fenômenos atmosféricos: vento, chuva, trovão \\
\hline Morfotopônimos & Topônimos relativos às formas geométricas \\
\hline Zootopônimos & Topônimos relativos aos animais \\
\hline
\end{tabular}

Fonte: Silva e Oliveira (2012)

\section{QUADRO 2-Classificação dos topônimos de Natureza Antropo-Cultural, segundo Dick}

\begin{tabular}{|l|l|}
\hline \multicolumn{1}{|c|}{ Categoria } & \multicolumn{1}{c|}{ Descrição } \\
\hline $\begin{array}{l}\text { Animotopônimos ou } \\
\text { Nootopônimos }\end{array}$ & $\begin{array}{l}\text { Topônimos relativos à vida psíquica, à cultura espiritual: vitória, } \\
\text { saudade, belo, feio }\end{array}$ \\
\hline Antropotopônimos & $\begin{array}{l}\text { Topônimos que dizem respeito a nomes próprios individuais: } \\
\text { prenome, hipocorístico, prenome mais alcunha, apelido de } \\
\text { famílias e prenome mais apelidos de família }\end{array}$ \\
\hline Axiotopônimos & $\begin{array}{l}\text { Topônimos relativos aos títulos e dignidades que acompanham } \\
\text { nomes próprios individuais }\end{array}$ \\
\hline Corotopônimos & $\begin{array}{l}\text { Topônimos relativos a nomes de cidades, países estados, regiões e } \\
\text { continentes }\end{array}$ \\
\hline Cronotopônimos & $\begin{array}{l}\text { Topônimos relativos aos indicadores cronológicos, representados } \\
\text { pelos adjetivos novo, nova, velho, velha }\end{array}$ \\
\hline Ecotopônimos & Topônimos relativos às habitações em geral \\
\hline Ergotopônimos & Topônimos relativos aos elementos da cultura material \\
\hline Etnotopônimos & $\begin{array}{l}\text { Topônimos relativos aos elementos étnicos, isolados ou não: } \\
\text { povos, tribos, castas }\end{array}$ \\
\hline Dirrematopônimos & Topônimos constituídos de frases ou enunciados linguísticos \\
\hline Hierotopônimos & $\begin{array}{l}\text { Topônimos relativos a nomes sagrados de crenças diversas, a } \\
\text { efemérides, religiosas, a associações e a locais de culto }\end{array}$ \\
\hline
\end{tabular}




\begin{tabular}{|l|l|}
\hline Hagiotopônimos & $\begin{array}{l}\text { Hierotopônimos relativos a nomes de santos da Igreja Católica } \\
\text { Romana }\end{array}$ \\
\hline Mitotopônimos & Hierotopônimos relativos a entidades mitológicas \\
\hline Historiotopônimos & $\begin{array}{l}\text { Topônimos relativos aos movimentos de cunho histórico, seus } \\
\text { membros e às datas comemorativas }\end{array}$ \\
\hline Hodotopônimos & Topônimos relativos às vias de comunicação \\
\hline Numerotopônimos & Topônimos relativos aos numerais \\
\hline Poliotopônimos & $\begin{array}{l}\text { Topônimos construídos com os vocábulos vila, aldeia, cidade, } \\
\text { povoação, arraial }\end{array}$ \\
\hline Sociotopônimos & $\begin{array}{l}\text { Topônimos relativos às atividades profissionais, aos locais de } \\
\text { trabalho e aos pontos de encontro da comunidade, aglomerados } \\
\text { humanos }\end{array}$ \\
\hline Somatopônimos & $\begin{array}{l}\text { Topônimos relativos metaforicamente às partes do corpo humano } \\
\text { ou animal }\end{array}$ \\
\hline
\end{tabular}

Fonte: Silva e Oliveira (2012)

O estudo da toponímia revela-se de grande importância, pois permite não só perceber a cosmovisão de um determinado povo, como também pode em muito contribuir para a reconstrução e/ou confirmação da história de um dado espaço. Segundo Vasconcellos, "pelo que respeita à linguagem, acontece frequentemente ir o glotólogo descobrir preciosidades no obscuro nome de um lugarejo ou no ingénuo falar de um ignorante" (GRANDE..., 1968, p. 82)

\subsection{Toponímia como veículo de cultura}

Um topônimo não se resume apenas em uma palavra. Por detrás de um topônimo há uma história, uma cultura, uma identidade, até mesmo um mito. Por este fato, um estudo da toponímia estritamente do ponto de vista linguístico não nos parece suficiente para perceber todo o seu valor. Assim sendo, alguns elementos extralinguísticos, nomeadamente o contexto do surgimento do topônimo, a entidade ou o povo que atribui o nome ao lugar são determinantes para percebermos o valor semântico/simbólico do topônimo. Conforme realça Dick, “o ‘dar nomes' e o 'conhecer os nomes dados’, para os primitivos em geral, tinha, realmente, uma conotação própria, porque pressupunha toda uma ocorrência ao mecanismo de domínio do 
ente, cujo nome de batismo, o primeiro, clânico, por certo, se tornava público". (1987, p. 97)

Os topônimos, bem como os antropónimos, são palavras como quaisquer outras dentro do sistema linguístico, ou seja, são signos linguísticos e, por isso mesmo, estão sujeitos às leis da gramática como as demais palavras da língua (VASCONCELLOS, 1931). Isso quer dizer que um topônimo é um signo linguístico cuja forma oral ou escrita é o significante e a localidade, povoação ou acidente geográfico corresponde ao significado, dado que os signos linguísticos "designam seres, objetos, processos, noções abstratas, por uma associação direta e recíproca do significante e do significado”. (GUIRAUD, 1989, p. 123)

Desse modo, a análise do processo de formação, da estrutura morfológica e do valor semântico dos topônimos também interessa à lexicologia. Grande parte dos topônimos recolhidos para o presente trabalho tem origem nas línguas bantu, especificamente o Kimbundu e entram no léxico do Português como empréstimos.

Muitos topônimos, ao entrarem no léxico do Português, sofrem alterações na sua estrutura morfológica motivados por processos fonéticos, de forma a se conformarem à estrutura da LP. Topônimos como Ngulungu, Ndalatandu, por exemplo, entram no léxico do Português como Golungo, N'dalatando. Outros, porém, mantêm a forma da língua de origem, adaptando-se apenas à grafia do Português: Kwanza $>$ Cuanza, Lwanda > Luanda.

A atribuição do nome a uma determinada localidade constitui um ato de importância capital para a pessoa, povo ou sistema ideológico que o atribui. Mais do que simplesmente nomear, significa a autoridade sobre aquele lugar por parte de quem o institui e a aceitação por parte dos habitantes da mesma circunscrição. Por essa razão, diversos topônimos referem-se ao patriarca, o responsável clânico, muitas vezes o primeiro a habitar a zona. Topônimos como Kifukusa, Kalandula, Kimbamba, Pedro Mufuma derivam de antropónimos tidos como os fundadores das aldeias.

Os topônimos revelam também pessoas que, em um dado momento da história, se dedicaram à causa da nação (por exemplo, rua Rainha Niinga, avenida Hoji ya Henda, avenida Deolinda Rodrigues, avenida Cónego Manuel das Neves, bairro Mártires de Kifangondo, largo Saidy Mingas) ou homenageiam um acontecimento histórico (aeroporto 4 de Fevereiro, largo 
4 de Fevereiro, marco histórico do Cazenga, praça da Independência, largo da Independência).

Os topônimos revelam igualmente épocas de domínio de uma dada ideologia política. $\mathrm{Na}$ fase de ocupação do território angolano, por exemplo, os portugueses procuraram dar nomes a diversas localidades de forma a expressar a sua presença e hegemonia sobre tais localidades. Desse modo, surgem topônimos como vila de Salazar, cidade de Carmona, vila de Duque de Bragança, Moçâmedes e Nova Lisboa em localidades como N'dalatando, Uije, ${ }^{2}$ Calandula, Namibe e Huambo.

Há casos em que, mesmo depois da alteração de um dado topônimo, o nome anterior continua a coexistir com o atual. Em Luanda, por exemplo, verifica-se a coexistência dos topônimos largo $1^{\circ}$ de Maio e praça da Independência (largo da Independência), largo do Baleizão e largo Saidy Mingas, estrada de Catete e avenida Deolinda Rodrigues.

Por isso, faz todo o sentido a afirmação de Seermann de que "a denominação dos lugares é, de fato, um processo político-cultural” (2005, p. 209). Aos topônimos que são transplantados e/ou aos que não refletem a identidade da localidade ou acidente geográfico que designam, Dick chama de designação superposta. Ainda a esse propósito, considera que:

[os] nomes são formas de língua virtuais, muitas vezes de natureza plástica, que se moldam às regiões de duas maneiras peculiares: ou designandoas segundo suas especificidades mais salientes, consubstanciadas, linguisticamente, em suas próprias semias; ou adotando uma denominação artificial, no sentido de seu distanciamento em relação ao grupo. Em outras palavras, o nome deixou/deixará de ser contextualizado ou introjetado pela comunidade porque seguiu o caminho inverso, advindo de fora para dentro do meio. (DICK, 2007, p. 142)

Para o presente trabalho, procedeu-se a recolha de um conjunto de topônimos que constituíram o corpus que serviu de base para análise. Os topônimos recolhidos referem-se sobretudo a nomes de comunas, setores, regedorias, aldeias e rios.

2 Também grafado Uíge. 


\subsection{Angola: situação sociolinguística}

Angola é um país africano situado na costa ocidental da parte austral do continente, tem uma extensão territorial de 1.246.700 quilômetros quadrados e dezoito províncias. Do ponto de vista etnolinguístico, o país é plurilingue e multiétnico, pois possui diferentes grupos étnicos, tendo cada um a sua própria língua.

Para a exequibilidade do presente trabalho, houve a necessidade de se delimitar a zona de circunscrição da investigação. Desse modo, selecionou-se um município da província de Malanje, neste caso o município com mesmo nome e capital provincial. Além da LP, predomina nesta região o Kimbundu.

A província de Malanje é constituída por catorze municípios, designadamente Malanje (a capital da província), Cacuso, Cangandala, Calandula, Quela, Quirima, Mucari (Caculama), Cambundi-Catembo, Cunda-dia-Baze, Caombo, Marimba, Cuaba Nzoji, Massango e Luquembo. A província é liderada politicamente por um governador provincial, ao passo que o município é dirigido por um administrador municipal. Com efeito, o topônimo Malanje designa quatro extensões territoriais, designadamente uma província, um município, uma comuna e uma cidade, além do rio Malanje.

Localizada na região centro-norte de Angola, a província de Malanje possui uma superfície de 903.302 quilômetros quadrados e uma população de 986.363 habitantes, segundo o Instituto Nacional de Estatística (2016), sendo o município de Malanje o mais populoso, com cerca de $490 \mathrm{mil}$ habitantes (INSTITUTO NACIONAL DE ESTATÍSTICA, 2014), portanto, mais da metade do total de habitantes de toda província.

A província de Malanje integra a região que tem como língua local o Kimbundu, sendo o povo designado de ambundu. Segundo Zau (2002, p. 61), o grupo etnolinguístico ambundu "foi a etnia que teve contatos mais intensos, com o mundo europeu". O autor afirma ainda que o grupo ambundu "[f]oi também, no século XVII, a primeira nação africana a ser sujeita a uma nação europeia. Talvez por esse fato, tenham também sido os mais aculturados de todos os outros grupos etnolinguísticos angolanos" (ZAU, 2002 , p. 61). Ainda segundo esse autor, o grupo etnolinguístico ambundu compreende os subgrupos Dembos, Maungos, Calandulas, Negolas, ${ }^{3}$

\footnotetext{
${ }^{3}$ Negola é uma forma aportuguesada de Ngola.
} 
Gingas, Holos, Bondos, Bângalas, Quissamas, Libolos, Hacos, Songos, Quibalas e Mussendes. A esses, Fernandes e Ntondo (2002, p. 44) acrescem os subgrupos Lwanda, Hungu, Ntemo, Puna e Bambeiro.

A língua Kimbundu é falada nas províncias de Malanje, Cuanza Norte, Bengo, Luanda e na zona norte do Cuanza Sul, além de zonas fronteiriças das províncias do Zaire e Uíje, e é, muitas vezes, designada de língua (m) bunda ou "ambundo".

O Kimbundu faz fronteiras ao norte com o Kikongo, a leste com o Cokwe e ao sul com o Umbundu e compreende, segundo Fernandes e Ntondo (2002, p. 44-45), as variantes "Holo, Ndongo, Kambondo, Kisama, Mgangala, Mbolo, Minungu, Ndembu, Ngola ou Jinga, Ngoya, Nkari, Ntemo, Puna, Songo e Xinji”.Do ponto de vista histórico, a extensão territorial conhecida hoje por província de Malanje pertencia ao reino do Ndongo, também designado por reino de Angola (ZAU, 2002). Para Santos, a cidade de Malanje entra para a história a partir de 1843, ano em que "Rodrigues Graça empreendeu a sua exploração, dando assim a conhecer a fertilidade do solo que já então produzia em abundância bens alimentares e pastagens" (SANTOS, 2005, p. 41). Malanje apresenta-se como uma cidade de capital importância por servir de ligação da zona litoral norte com o leste de Angola, nomeadamente as províncias da Lunda Norte, da Lunda Sul e do Moxico.

À semelhança do resto do país, em Malanje coexistem a língua local, o Kimbundu, e o Português, que é a língua oficial do país, segundo a Constituição da República de Angola (CRA). O Kimbundu predomina sobretudo nas zonas rurais, enquanto o Português predomina nos centros urbanos. O Português é a única língua que cobre toda a extensão do território angolano, sendo, pois, as línguas locais de caráter regional.

O período pré-independência, em Angola, foi marcado pela política de exclusão das línguas locais, designada por Costa (2006) de processo da "glotofagia". Tal política teve como ápice o período de governação de Norton de Matos, então alto-comissário de Angola, que proibiu o uso das línguas locais em favor do Português. Apesar de uma atitude tão adversa, as línguas locais mantiveram-se vivas e influenciaram grandemente a língua dominante.

${ }^{4}$ Do Kimbundu, ambundu, que significa negros, pretos. 
Alcançada a independência, verificou-se um esforço na promoção das línguas locais, contudo, sem prejuízo algum para a LP. Costa (2006, p. 46) considera que "a manutenção e difusão da língua portuguesa e a reabilitação dos idiomas bantu nacionais não traduzem medidas incompatíveis entre si”, uma vez que "a intervenção do Estado na resolução dos problemas linguísticos deve contribuir para a promoção do querer viver juntos, elemento básico da coesão e da identidade nacional" (REIS, 2006, p. 62). Portanto, a LP foi adotada como língua oficial do Estado e língua de unidade nacional, dado que "a existência da língua portuguesa em Angola transcorre numa situação de heterogeneidade idiomática" (COSTA, 2006, p. 47). Esta heterogeneidade decorre do fato de o território angolano ser fruto de vários reinos, tendo cada um a sua própria língua.

O esforço para a promoção das línguas angolanas de origem africana levou, em 1987, sob proposta do Instituto de Línguas Nacionais (ILN), o Conselho de Ministros da então República Popular de Angola a aprovar a Resolução no 3/87 (ANGOLA, 1987), que aprova a título experimental os alfabetos de seis línguas, nomeadamente Kikongo, Kimbundu, Cokwe, Umbundu, Mbunda e Oxikwanyama.

Atualmente o Português é a única língua que goza de estatuto constitucional em Angola, conforme a citação da CRA: "1. A língua oficial da República de Angola é o português. 2. O Estado valoriza e promove o estudo, o ensino e a utilização das demais línguas de Angola, bem como das principais línguas de comunicação internacional”. (ANGOLA, 2010)

O fato de as "demais línguas de Angola" não terem merecido qualquer menção na CRA tem suscitado diversas críticas dos que defendem uma maior promoção das LA, ou seja, "línguas nacionais". Chivinga, por exemplo, levanta determinadas questões que se julgam pertinentes, conforme a citação:

a. Se a língua oficial é o português, que estatuto têm as outras línguas?

b. As funções do Estado relativamente às 'demais línguas', segundo este artigo, resumem-se a valorizar e promover os estudos e o ensino daquelas. Posto isto, a quem cumpre as restantes funções, como sejam, por exemplo, a protecção jurídica, a preservação, a regulação da convivência linguística numa nação plurilingue?

c. Que pessoas representam 'as demais línguas de Angola'?

d. Como deverá levar-se a efeito a citada valorização e promoção? 
e. Não é feita, inclusivamente, qualquer referência ao carácter multilingue e plurilingue de uma nação que conta com mais de nove grupos etnolinguísticos. (CHIVINGA, 2014, p. 53)

É inegável o fato de que as línguas dos diversos grupos etnolinguísticos de Angola não gozam de qualquer estatuto constitucional, recebendo mesmo a vaga designação de "demais línguas de Angola", por um lado, e, por outro, um tratamento idêntico ao das "principais línguas de comunicação internacional", uma vez que ambas surgem no mesmo parágrafo, ao passo que o estatuto do Português é tratado em parágrafo distinto. O texto constitucional é omisso quanto às designações dessas "demais línguas de Angola".

Não obstante isso, a alínea n) do artigo $21^{\circ}$ da CRA afirma que é tarefa fundamental do Estado angolano "[p]roteger, valorizar e dignificar as línguas angolanas de origem africana, como património cultural e promover o seu desenvolvimento, como línguas de identidade nacional e de comunicação".

$\mathrm{O}$ artigo $16^{\circ}$ da Lei $\mathrm{n}^{\circ} 17 / 16$, de 7 de Outubro de 2016, também chamada Lei de Bases do Sistema de Educação e Ensino, vigente em Angola, estabelece o seguinte:

1. O ensino deve ser ministrado em português. 2. O Estado promove e assegura as condições humanas, científico-técnicas, materiais e financeiras para a expansão e generalização da utilização, no ensino, das demais línguas de Angola [...] 3. Sem prejuízo do previsto no $\mathrm{n}^{\circ} 1$ do presente artigo, e como complemento e instrumento de aprendizagem, podem ser utilizadas línguas de Angola nos diferentes subsistemas de, nos termos a regular em diploma próprio. (ANGOLA, 2016)

Como se pode observar, há um claro privilégio da LP em relação às LA. Como se depreende do artigo transcrito, independentemente da língua materna da criança, por exemplo, no ensino primário, ela tem de ser forçosamente ensinada em Português, já que a lei cria exceção apenas para o ensino de adultos.

\section{Metodologia da investigação}

Para a realização deste trabalho, constituiu-se um corpus de topônimos da região em estudo. De acordo com Costa (2005), a constituição de um corpus leva-nos a refletir sobre os critérios intervenientes no processo de 
seleção, organização e sistematização de textos que devem ser integrados no respectivo corpus. Para Rastier (2005), o objeto empírico da linguística é constituído por textos orais e escritos, e não simplesmente por palavras ou frases, nem devem ser encarados de forma isolada. Desse modo, a constituição do corpus deve ser feita em função de uma tipologia de textos, ou seja, de documentos.

Nesse sentido, Costa (2005) defende que a definição de um corpus implica a reunião de um conjunto de textos sob a mesma etiqueta. Segundo a mesma autora, esse conjunto de textos mantêm relações de semelhanças entre si, tanto a nível da microestrutura quanto a nível da macroestrutura. Nessa conformidade, convém que os textos que constituem o corpus sejam homogêneos, ou seja, partilhem entre si semelhanças, sobretudo no que diz respeito ao objeto de análise. O corpus deve igualmente ser objetivo, isto é, deve conformar-se à finalidade do trabalho para o qual é constituído (RASTIER, 2005).

Tendo em conta o objeto do presente estudo, é importante perceber que a investigação toponímica pode ser feita a partir de documentos escritos, como mapas cartográficos, documentos administrativos etc. (TAVARES; ISQUERDO, 2006; CASTIGLIONI; BARROS; ISQUERDO, 2012), ou de fontes orais, através de uma pesquisa de campo para se proceder a recolha de dados (SEABRA, 2004). Com efeito, o corpus do presente trabalho é constituído por documentos diversos, entre escritos - recolhidos da Administração Municipal de Malanje (2012) e da Direção Provincial do Instituto Geográfico e Cadastral de Angola - e orais - recolhidos durante a pesquisa de campo e mediante consulta às autoridades tradicionais do município.

Para a pesquisa documental, utilizou-se o mapa digital da cidade de Malanje e três grelhas com a divisão administrativa do município obtidos da Administração Municipal de Malanje e da Delegação Provincial do Instituto Geográfico e Cadastral de Angola (IGCA). Utilizou-se também documentos fotográficos de placas de sinalização rodoviária, bem como de painéis de identificação de instituições.

Para os documentos orais, serviu-se de informantes locais que forneceram dados relativos à divisão político-administrativa das comunas, aldeias, bairros e povoações. Por conseguinte, realizou-se três encontros (um em cada comuna) com representantes das autoridades tradicionais das diversas aldeias de cada comuna, tendo participado mais de sessenta 
informantes, entre os quais regedores e sobas, utilizando a técnica de focus group. Os referidos encontros tiveram como objetivos validar a informação recolhida e compreender a origem e o significado dos respectivos topônimos, comparando com a informação do dicionário. Depois da realização desses encontros, tornou-se possível a constituição do corpus que serviu de base ao presente trabalho.

\section{Apresentação e discussão dos dados}

O corpus deste trabalho é constituído por um total de 173 topônimos, dos quais 93 são de língua Kimbundu, equivalentes a 53,75\% do corpus; 58 topônimos de LP, equivalentes a 33,52\%; e 22 topônimos híbridos, equivalentes a $12,71 \%$. Dos 22 topônimos híbridos, 10 topônimos são Kimbundu-Português (5,78\%); 9 topônimos são PortuguêsKimbundu(5,20\%); e 3 topônimos são em Português e outra língua ${ }^{5}(1,73 \%$ do total do corpus).

GRÁFICO1 - Distribuição dos topônimos segundo a língua de origem

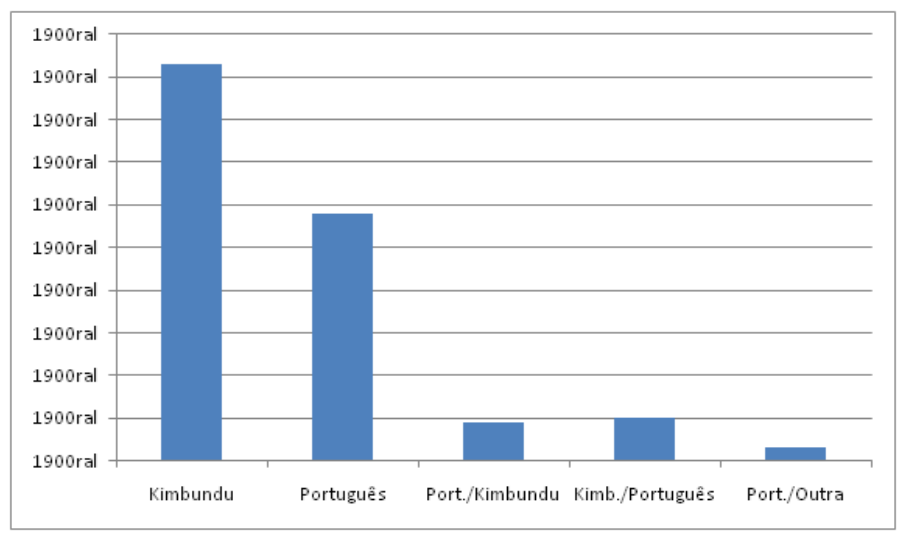

Fonte: Elaborado pelo autor.

Os dados apresentados revelam que há algum equilíbrio na distribuição dos topônimos por línguas, sobretudo o Português e o Kimbundu. Contudo, a realidade indica que a área urbana, segundo o nosso corpus, apresenta

\footnotetext{
${ }^{5}$ Consideramos, aqui, outra qualquer língua que não seja o Kimbundu ou o Português. Desse grupo de topônimos, dois são Português-Francês e um Português e língua moçambicana.
} 
apenas dois topônimos em Kimbundu, nomeadamente a designação da cidade e o antropotopônimo Hoji ya Henda. Por outro lado, nas zonas rurais são escassos os topônimos em LP e abundam sobretudo os topônimos em Kimbundu. Já nas áreas suburbanas, podem encontrar-se topônimos quer em LP quer em Kimbundu, sendo estes predominantes.

Dos 173 topônimos recolhidos, selecionámos 147 para uma base de dados. Os demais topônimos não constam da base de dados por não terem sido validados no ato da recolha, em virtude de as autoridades das respectivas localidades não se terem feito presentes nos encontros organizados com as autoridades tradicionais locais.

O fato de a maior parte dos topônimos não apresentar fontes escritas fez com que se adotasse uma forma de escrita para os referidos topônimos. Assim sendo, a forma adotada é aportuguesada, conforme o Decreto $n^{\circ} 339 / 1970$, de 16 de julho de 1970, e o Decreto no 50/1971, de 23 de fevereiro de 1971, em que todos os topônimos com origem nas línguas locais são aportuguesados, bem como em obediência à Lei no 14/2016 (ANGOLA, 2016), que estabelece que os topônimos são escritos em LP, seguindo a grafia latina. Por exemplo, o topônimo Malanje grafou-se sempre com $<j>$ e não com $<\mathrm{g}>$, como rezam os já citados documentos.

Do ponto classificatório, distribuímos os topônimos segundo o modelo de Dick. O Gráfico 2 mostra a incidência dos topônimos por cada uma das classes taxionômicas referidas.

GRÁFICO 2 - Distribuição numérica dos topônimos por classes taxionômicas

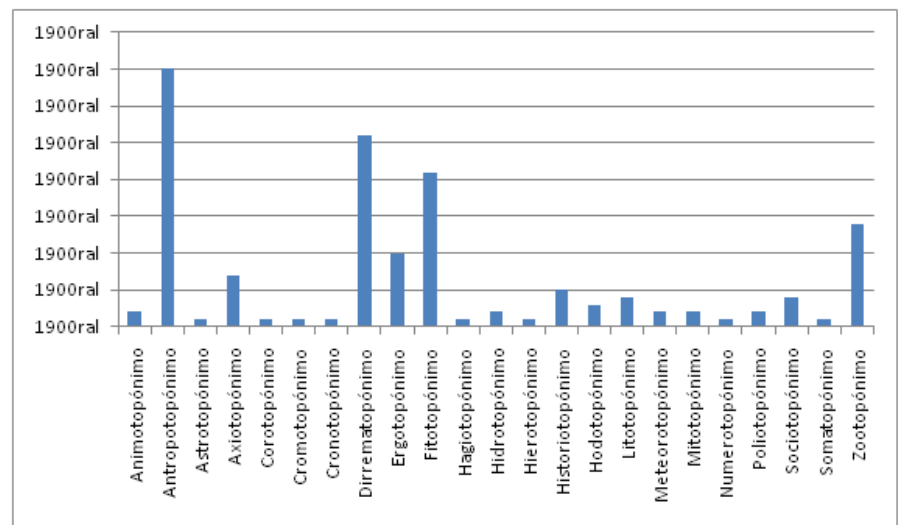

Fonte: Elaborado pelo autor 
Com vista a proceder-se uma análise mais cuidadosa, entendeu-se apresentar 120 topônimos em um quadro com as principais características dos mesmos, do qual se apresenta um exemplo no Quadro 3.

QUADRO 3 - Morfologia e semântica dos topônimos

\begin{tabular}{|c|c|c|c|c|c|}
\hline $\mathbf{N}^{\mathbf{o}}$ & $\begin{array}{c}\text { Língua de } \\
\text { origem }\end{array}$ & Topônimo & $\begin{array}{c}\text { Forma } \\
\text { original }\end{array}$ & $\begin{array}{c}\text { Estrutura } \\
\text { morfológica }\end{array}$ & Significado \\
\hline 01 & Kimbundu & Cabombo & Kambombo & $\mathrm{N}[\mathrm{S}$ sing] & mandioca demolhada \\
\hline 02 & Kimbundu & Cajimbinza & Kajimbinza & $\mathrm{N}[$ Prefsing $+\mathrm{Spl}]$ & camisa \\
\hline 03 & Kimbundu & Caluhia & Kaluhia & $\mathrm{N}[$ Ssing] & espécie de planta \\
\hline 04 & Kimbundu & Camatemo & Kamatemu & $\mathrm{N}[\mathrm{Spl}]$ & enxadas \\
\hline 05 & Kimbundu & Cambaxe & Kambaxi & $\mathrm{N}[$ Ssing $]$ & cágado \\
\hline 06 & Kimbundu & Camilemba & Kamilemba & $\mathrm{N}[$ Prefsing + Spl $]$ & $\begin{array}{l}\text { espécie de árvore } \\
\text { típica da região }\end{array}$ \\
\hline 07 & Kimbundu & Camilungo & Kamilungu & $\mathrm{N}[$ Prefsing + Spl $]$ & $\begin{array}{l}\text { espécie de planta, } \\
\text { erva-moira }\end{array}$ \\
\hline 08 & Kimbundu & Camueia & Kamweya & $\mathrm{N}[$ Ssing] & $\begin{array}{l}\text { espécie de árvore } \\
\text { frutífera }\end{array}$ \\
\hline 09 & Kimbundu & Camueje & Kamweji & $\mathrm{N}[\mathrm{S}$ sing] & Luar \\
\hline 10 & Kimbundu & Candende & Kandende & $\mathrm{N}[\mathrm{S}$ sing] & dendém \\
\hline 11 & Kimbundu & Cassefo & Kasefu & $\mathrm{N}[$ Ssing] & $\begin{array}{l}\text { espécie de animal } \\
\text { ruminante bovídeo }\end{array}$ \\
\hline 12 & Kimbundu & Cassequele & Kasekele & $\mathrm{N}[\mathrm{S}$ sing] & areia \\
\hline 13 & Kimbundu & Catende & Katende & $\mathrm{N}[\mathrm{S} \sin \mathrm{g}]$ & lagartixa \\
\hline 14 & Kimbundu & Cauenda & Kawenda & $\mathrm{N}[$ Ssing] & $\begin{array}{l}\text { pau-de-fileira, } \\
\text { cumeeira }\end{array}$ \\
\hline 15 & Kimbundu & Dimba & Dimba & $\mathrm{N}[\mathrm{S}$ sing] & $\begin{array}{l}\text { instrumento musical } \\
\text { da região }\end{array}$ \\
\hline 16 & Kimbundu & Fumba & $(\mathrm{Ku})$ Fumba & V & $\begin{array}{l}\text { dar alguma coisa } \\
\text { menos do que o } \\
\text { devido; prejudicar }\end{array}$ \\
\hline 17 & Kimbundu & Gumba & Ngumba & $\mathrm{N}[$ Ssing] & filho único \\
\hline 18 & Kimbundu & Guvo & Nguvu & $\mathrm{N}[\mathrm{S}$ sing] & hipopótamo \\
\hline
\end{tabular}




\begin{tabular}{|c|c|c|c|c|c|}
\hline 19 & Kimbundu & Lau & Lahu & $\mathrm{N}[\mathrm{S} \sin g]$ & lagarto \\
\hline 20 & Kimbundu & Lombe & Kulombela & V & rogar \\
\hline 21 & Kimbundu & Luma & $\begin{array}{l}\text { Luma } \\
\text { (kuluma) }\end{array}$ & $\mathrm{N}[\mathrm{S} \sin \mathrm{g}]$ & $\begin{array}{l}\text { rumor de chuva, } \\
\text { ribombar }\end{array}$ \\
\hline 22 & Kimbundu & Malanje & Malanji & $\mathrm{N}[\mathrm{Spl}]$ & pedras \\
\hline 23 & Kimbundu & Micanda & Mikanda & $\mathrm{N}[\mathrm{Spl}]$ & cartas \\
\hline 24 & Kimbundu & Mucongo & Mukongo & $\mathrm{N}[\mathrm{S}$ sing] & caçador \\
\hline 25 & Kimbundu & Ndeia & Ndeya & $\mathrm{N}[\mathrm{S}$ sing] & corruptela de aldeia \\
\hline 26 & Kimbundu & Ngola Luíje & Ngola Lwiji & $\mathrm{NC}[$ Ssing + Ssing] & pedaços de ferro - rio \\
\hline 27 & Kimbundu & Pombo & Pombo & $\mathrm{N}[\mathrm{S}$ sing $]$ & macaco \\
\hline 28 & Kimbundu & Quiala & Kyala & $\mathrm{N}[\mathrm{S} \sin g]$ & homem \\
\hline 29 & Kimbundu & Quifucussa & Kifukusa & $\mathrm{N}[\mathrm{S}$ sing $]$ & significado incerto \\
\hline 30 & Kimbundu & Quihunga & Kihunga & $\mathrm{N}[\mathrm{S}$ sing $]$ & espécie de inseto \\
\hline 31 & Kimbundu & Quima & Hima & $\mathrm{N}[\mathrm{S} \sin g]$ & macaco \\
\hline 32 & Kimbundu & Quimaco & Kimaku & $\mathrm{N}[\mathrm{S} \sin g]$ & $\begin{array}{l}\text { sinal, ponto de } \\
\text { referência }\end{array}$ \\
\hline 33 & Kimbundu & Quimbamba & Kimbamba & $\mathrm{N}[\mathrm{S}$ sing $]$ & carga, bagagem \\
\hline 34 & Kimbundu & Quimonha & Kimonya & $\mathrm{N}[\mathrm{S} \sin g]$ & preguiçoso \\
\hline 35 & Kimbundu & Quingungo & Kingungu & $\mathrm{N}[\mathrm{S}$ sing $]$ & eco \\
\hline
\end{tabular}

Fonte: Elaborado pelo autor

\subsection{Estrutura morfológica dos topônimos}

No que diz respeito à estrutura morfológica, dos topônimos apresentados, 72 apresentam forma simples, 47 apresentam forma composta e 1 é acrônimo. Do conjunto dos 72 topônimos simples, 32 são derivados e os outros 40 apresentam formas de base, ${ }^{6}$ conforme o Gráfico 3.

\footnotetext{
${ }^{6}$ Para os topônimos de origem Kimbundu, considerou-se forma de base o radical ligado ao prefixo de classe ao qual aparece sempre ligado. Sempre que o radical aparece ligado a outro prefixo, considerou-se um caso de derivação por substituição.
} 
GRÁFICO3 - Distribuição dos topônimos segundo a sua estrutura

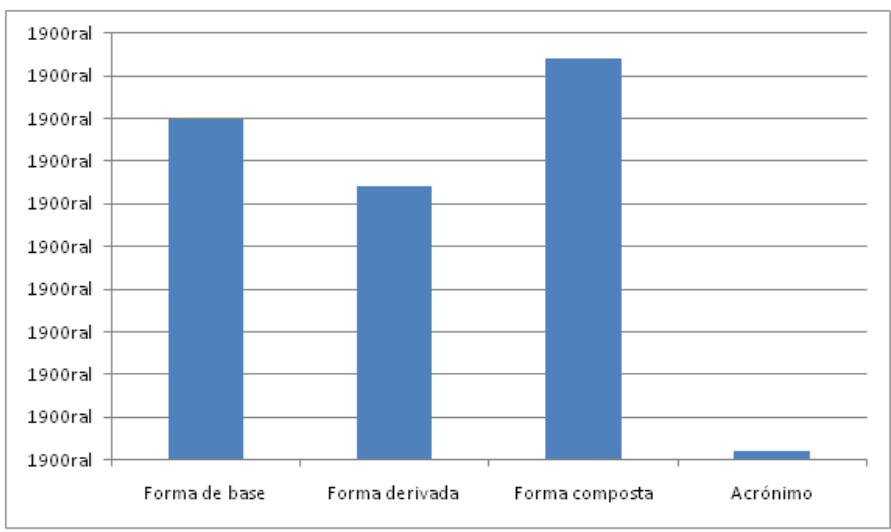

Fonte: Elaborado pelo autor.

Todos os topônimos derivados são, pois, de origem Kimbundu, não havendo, portanto, topônimos derivados de origem portuguesa. As combinações comuns são [Pref + Pref + Rad] e [Pref $+\varnothing+\mathrm{Rad}]$, como se vê no Quadro 4.

QUADRO 4 - Topônimos formados pelo processo de derivação

\begin{tabular}{|l|c|l|}
\hline Tipo de formação & Quantidade & \multicolumn{1}{c|}{ Exemplos } \\
\hline Pref + Pref + Rad & 13 & $\begin{array}{l}\text { Camatemo, Camueia, Camueje, Camilemba, Cajimbinza, } \\
\text { Camembe, Camibafo, Caminzaje, Cajimbenza, Camissoxe, } \\
\text { Camissombo, Camatende, Camacondeca }\end{array}$ \\
\hline Pref $+\varnothing+$ Rad & 16 & $\begin{array}{l}\text { Cambaxi, Quima, Cabombo, Cassefo, Catende, Quinjango, } \\
\text { Cassequel Candende, Cassembele, Candumbu, Cassembala, } \\
\text { Catunga, Cangambo, Candendo, Cahunje, Canânbua }\end{array}$ \\
\hline Pref $+\mathrm{Rad}$ & 03 & Quima, Quiala, Caiala \\
\hline
\end{tabular}

Fonte: Elaborado pelo autor.

Ainda no que diz respeito ao processo de derivação dos topônimos de origem Kimbundu, destacam-se determinadas combinações de prefixos de que se fala adiante. Todavia, de forma geral, grande parte dos topônimos de origem Kimbundu recolhidos começa pelos prefixos de classe 7 e 12, respectivamente ki- e ka-, este último mais abundante. 
QUADRO 5 - Topônimos formados pelos prefixos ki- e ka-

\begin{tabular}{|c|c|c|c|c|c|}
\hline Classe & $\begin{array}{l}\text { Prefixo de } \\
\text { classe }\end{array}$ & Exemplo & $\begin{array}{c}\text { Estrutura } \\
\text { morfológica }\end{array}$ & $\begin{array}{c}\text { Forma } \\
\text { corrente }\end{array}$ & $\begin{array}{c}\text { Forma } \\
\text { aportuguesada }\end{array}$ \\
\hline \multirow{7}{*}{7} & \multirow{7}{*}{ ki- } & Kingungu & ki+ngungu & Kingungu & Quingungo \\
\hline & & Kyala & ki+yala & Dyala & Quiala \\
\hline & & Kisanji & ki+sanji & Kisanji & Quissanje \\
\hline & & Kinjangu & ki+njangu & Njangu & Quinjango \\
\hline & & Kimbamba & $\mathrm{ki}+\mathrm{mbamba}$ & kimbamba & Quimbamba \\
\hline & & Kimaku & $\mathrm{ki}+\mathrm{maku}$ & Kimaku & Quimaco \\
\hline & & Kima & ki+hima & Hima & Quima \\
\hline \multirow{8}{*}{12} & \multirow{8}{*}{ ka- } & Kambaxi & $\mathrm{ka}+\varnothing+\operatorname{mbaxi}$ & Mbaxi & Cambaxe \\
\hline & & Kambombo & $\mathrm{ka}+\varnothing+\mathrm{mbombo}$ & mbombo & Cabombo \\
\hline & & Kamatemu & $\mathrm{ka}+\mathrm{ma}+\mathrm{temu}$ & Ditemu & Camatemo \\
\hline & & Kamweya & $\mathrm{ka}+\mathrm{mu}+$ eya & Mweya & Camueia \\
\hline & & Kamweji & $\mathrm{ka}+\mathrm{mu}+\mathrm{eji}$ & Mweji & Camueje \\
\hline & & Kasekele & ka+sekele & Sekele & Cassequele \\
\hline & & Kamisombo & $\mathrm{ka}+\mathrm{mi}+\mathrm{sombo}$ & musombo & Camissombo \\
\hline & & Kamitangu & $\mathrm{ka}+\mathrm{mi}+$ tangu & Tangu & Camitango \\
\hline
\end{tabular}

Fonte: Elaborado pelo autor.

Conforme o Quadro 5, os prefixos ki- e ka- ocorrem frequentemente em topônimos. Convém realçar que, em Kimbundu, o prefixo ka- marca o diminutivo e o prefixo ki- é, por vezes, usado para marcar o grau aumentativo dos nomes (COSTA, 2006). Todavia, tal não sucede nos topônimos, ou seja, os falantes nativos não reconhecem o valor diminutivo/aumentativo desses prefixos nos topônimos.

Ao efetuar uma análise da proposta de quadro de prefixos apresentada por Quintão (1934), tendo como referência o exemplo kaditadi/tuditadi, Costa afirma que: 
Antes de o nome adquirir o valor correspondende [sic] à semântica do diminutivo, ele pertence a uma determinada classe diferente da 10. ${ }^{\mathrm{a}}$, a cujo mecanismo de funcionamento obedece. O termo ditadi a que o autor recorre para a ilustração da classe do diminutivo é tomado da $4 .^{\text {a }}$ classe. Tem como especificador de classe o morfema di, como se observa na fronteira inicial do próprio termo, e forma o plural em ma, ditadi (pedra)/ matadi (pedras). Assim, plural do diminutivo não será tuditadi, conforme o autor da proposta em análise sugere, mas sim, tumatadi. $\mathrm{O}$ autor associa o singular do termo ao plural do diminutivo do mesmo, o que é inaceitável, em quimbundo. Pois, o nome mantém a estrutura anterior à aplicação do diminutivo. (COSTA, 2006, p. 124)

Da citação acima transcrita podemos aferir que Costa defende que, em Kimbundu, a combinação de um prefixo plural com um nome singular é inaceitável. Assim sendo, baseado na lógica do autor, o inverso também seria inaceitável, ou seja, a combinação de prefixo singular com um nome plural. Isso acontece porque "o nome mantém a estrutura anterior à aplicação do diminutivo" (COSTA, 2006, p. 124). Dado o fato de os diminutivos serem palavras derivadas - nestes casos, derivados por adição de prefixo (FERNANDES; NTONDO, 2002) -, o prefixo que marca o diminutivo deve concordar em número com o nome a que se junta, como representado abaixo:

$$
\begin{aligned}
& \text { Prefsing }+ \text { Nsing }] \text { ou }[\text { Prefpl }+ \text { Npl }] \\
& \text { Kaditadi }=\text { ka- }[\text { Prefsing }]+\operatorname{ditadi}[\text { Nsing }] \\
& \text { Tumatadi }=\text { tu- }[\text { Prefpl }]+\operatorname{matadi}[\mathrm{Npl}]
\end{aligned}
$$

Todavia, uma análise dos topônimos recolhidos mostra-nos ser frequente a ocorrência de nomes derivados que não obedecem à combinatória acima representada. Topônimos como Camueia (Kamweya) e Camueje (Kamweji), por exemplo, obedecem à lógica do pensamento de Costa, já que combinam prefixo singular com nome singular. Porém, topônimos como Camilungo (Kamilungu), Camilemba (Kamilemba), Camissombo (Kamisombo), Camitango (Kamitangu), Camatemo (Kamatemu), Camahaxe (Kamawhaxi), Camatende (Kamatende), Cajimbenza (Kajimbenza) e Cajimbinza (Kajimbinza) não se adequam ao princípio defendido por Costa, uma vez que combinam prefixo singular com nome plural, apresentando, portanto, o seguinte esquema: 


$$
\begin{aligned}
& {[\text { Prefsing }+\mathrm{Npl}]} \\
& \text { Ka- }[\text { Prefsing }]+\text { milemba }[\mathrm{Npl}] \\
& \text { Ka- }[\text { Prefsing }]+\text { jimbenza }[\mathrm{Npl}]
\end{aligned}
$$

Quanto aos 47 topônimos compostos, todos são formados por justaposição, isto é, congregam mais de uma palavra, conservando cada uma o seu acento tónico. Grande maioria desses topônimos é de origem antroponímica. Nesse aspecto, as combinações substantivo-substantivo e substantivo-preposição-substantivo são as mais frequentes. Nos topônimos Infante Sagres e Capelo Ivens, verifica-se a omissão da preposição de e da conjunção $e$, respectivamente.

QUADRO 6 - Topônimos formados pelo processo de composição

\begin{tabular}{|c|c|l|}
\hline Tipo de formação & Quantidade & \multicolumn{1}{|c|}{ Exemplos } \\
\hline$S+S$ & 15 & $\begin{array}{l}\text { Camoma Ngando, vila Matilde, Serpa Pinto, Capelo [e] } \\
\text { Ivens, Miguel Bombarda }\end{array}$ \\
\hline$S+$ Prep $+S$ & 9 & $\begin{array}{l}\text { Zumba-ia-Ganga, Calunga Camalemba, Toma de } \\
\text { Água, Fonte do Amor, Carreira de Tiro, Campo de } \\
\text { Aviação, Luís de Camões }\end{array}$ \\
\hline$S+A D J$ & 4 & Cassanje Caluama, Soldado Desconhecido, Terra Nova \\
\hline$A D J+S$ & 2 & Bela Fama, Santo António \\
\hline$S+S+P r e p+S$ & 4 & Governador Silva de Carvalho, Major Sales de Brito \\
\hline$S+S+S$ & 2 & Duarte Pacheco Pereira, largo Vaz Osório \\
\hline$S+P r e p+A r t+S$ & 2 & desvio do Quissol, avenida dos Combatentes \\
\hline$S+S+P r e p+A r t+S$ & 1 & Tomás Vieira da Cruz \\
\hline$S+A D J+N m r$ & 1 & Estrada Nacional 230 \\
\hline$S+P r e p+A D V$ & 4 & Carianga do Meio, Catombe de Baixo \\
\hline$N m r+P r e p+S$ & 2 & 15 de Agosto, 10 de Dezembro \\
\hline$V+S$ & 1 & Cula Muxito \\
\hline
\end{tabular}

Fonte: Elaborado pelo autor. 


\section{Princípios para a harmonização gráfica dos topônimos}

Em uma situação de contato linguístico, é normal que as línguas se influenciem mutuamente. Tal é o caso da LP e do Kimbundu. Interessa, aqui, tratar dessas influências estritamente a nível lexical, ou seja, os empréstimos linguísticos. Como já se disse, tanto aLP quanto o Kimbundu tomaram emprestadas determinadas unidades lexicais uma da outra. O que importa é perceber como tais unidades lexicais são integradas ao léxico de cada língua. Kirkness (1979, p. 226) assegura que há "empréstimos de línguas estrangeiras em todas as línguas". Em um mundo de intensas relações entre pessoas de diferentes comunidades linguísticas, torna-se praticamente impossível existir uma língua que não tenha, no seu léxico, unidades linguísticas oriundas de outras línguas, dado que, "[p]or contato com outros povos e com outras culturas, novas palavras podem ser incorporadas nos vocabulários" (RAPOSO et al, 2013, p. 24). Embora seja um fenômeno praticamente incontornável, os empréstimos nem sempre são bem-vistos por certos estudiosos e falantes de determinadas línguas (VILLALVA, 2008), não sendo o Kimbundu uma exceção. Contudo, os empréstimos justificamse pela necessidade de se referir a determinadas realidades e fenômenos inexistentes na língua-alvo.

Nessa conformidade, as unidades lexicais tomadas de outras línguas podem obedecer a diversos processos de integração no léxico da línguaalvo. Azeredo (2012) destaca processos como xenismos, adaptações e decalques, além das siglas e acrônimos como mecanismos de integração dos estrangeirismos em uma determinada língua. Os xenismos consistem na conservação da forma gráfica de origem do estrangeirismo, como em mouse e em personal trainer. As adaptações consistem na submissão do estrangeirismo à morfologia do Português, como sucede em banda (do inglês band, conjunto instrumental). Nos decalques há uma tradução literal do estrangeirismo, como em alta costura (do francês baute couture). Finalmente, nas siglas e acrônimos empregam-se as iniciais das palavras constitutivas da expressão estrangeira, sendo que as siglas são foneticamente realizadas de forma soletrada - como em PC (personal computer), CD (compact disk) - e os acrônimos são realizados como um contínuo, à semelhança das demais palavras da língua - como em laser (light amplification by stimulated emission radiation) e radar (radio detecting and ranging). 
Por outro lado, costuma estabelecer-se diferença entre estrangeirismos e empréstimos. Kirkness (1979, p. 225) entende por estrangeirismo "uma palavra tomada doutra língua, mais ou menos sem modificações”. Por sua vez, Mateus et al (1990, p. 415) definem empréstimos como "palavras provenientes de outras línguas e adaptadas à nova língua”. Nesse caso, há, pois, certa diferença entre estrangeirismo e empréstimo. Certa palavra dirse-á estrangeirismo enquanto mantiver a sua forma da língua de origem e/ou não tiver sido introduzida no léxico da língua-alvo. No momento em que um estrangeirismo é introduzido no léxico da língua-alvo, passa a designar-se empréstimo, podendo sofrer transformações da sua forma original. Para Vilela (1994, p. 16), "a adaptação dos elementos importados pode variar, indo a escala de adaptação desde o acomodamento até ao bloqueamento total no aspecto formal". O mesmo autor considera ainda que " $[\mathrm{o}]$ empréstimo, ao ser bloqueado, adapta-se, com o tempo, gráfica e fonicamente, à língua” (VILELA, 1994, p. 17). Nessa perspectiva, os topônimos, sendo unidades linguísticas como quaisquer outras, não são alheios a esses fenômenos linguísticos e podem, por isso mesmo, sofrer transformações em função destes.

No que à toponímia diz respeito, o Ministério da Cultura defende que os topônimos africanos sejam escritos segundo a ortografia das línguas africanas (TOPÔNIMOS..., 2014, p. 34), sem ter em conta o fenômeno de empréstimo linguístico. Assim, os empréstimos aportuguesados Cuanza, Cuando e Quiçama, por exemplo, devem ser escritos Kwanza, Kwando e Kisama, chocando-se com as regras de ortografia da LP.

Defende-se aqui a promoção e valorização das LA. Entretanto, é necessário que se dê à LP o devido valor como língua de unidade nacional, respeitando-se igualmente as suas regras. Quando não se respeita determinados fenômenos linguísticos, frutos do contato de línguas, a cientificidade desses argumentos é posta em causa. Por outro lado, a advogada tese de que as LA possuem "alfabetos próprios" não leva em consideração, muitas vezes, que os mesmos alfabetos são adaptações do alfabeto latino, posto que as LA não possuem uma tradição escrita, mas sim oral. As primeiras tentativas de escrita das LA foram empreendidas por cidadãos europeus, que transplantaram os alfabetos das suas línguas para LA (COELHO, 1999). Por esse fato, se é legítimo apossar-se do alfabeto latino e

\footnotetext{
${ }^{7}$ A grafia correta seria Kwandu.
} 
considerá-lo "nosso", julga-se razoável aceitar-se determinados fenômenos linguísticos frutos do contato entre as LA e a LP.

A harmonização gráfica dos topônimos tem por objetivo eliminar as várias formas de escrita existentes e procurar adequar a escrita dos topônimos segundo os critérios ortográficos dos sistemas linguísticos em causa, o Kimbundu e o Português. As propostas que se apresentam poderão revelar alguma arbitrariedade (CASTRO, 1991), sobretudo no caso da LP, na medida em que, em determinados casos, há que optar por escrever um dado topônimo com um determinado grafema e não com outro que também representa o mesmo fonema. Nesses casos, quando diversos grafemas representam o mesmo fonema, optamos por aquele que, na língua de origem, representa o mesmo som.

Há casos de topônimos africanos cuja grafia, muitas vezes aportuguesada, não suscita grandes divergências. Isto é frequente em topônimos como Malanje, Maxinde, Fumba, Luma, Tuma ou Lombe, cujas estruturas são idênticas tanto Português como no Kimbundu. Salienta-se que o topônimo Malanje era grafado com $<\mathrm{g}\rangle$.

Desse modo, sempre que a estrutura morfológica do topônimo coincide em ambos sistemas linguísticos, a sua forma gráfica não oferece divergências.

\subsection{Critérios de aportuguesamento}

Em primeiro lugar, é necessário ter-se em conta a convivência da LP com as línguas locais. Em segundo, as unidades linguísticas - os topônimos - aportuguesados integram o léxico do português angolano. Desse modo, os topônimos aportuguesados não pertencem ao léxico das LA, uma vez que as formas originais continuam a integrar o léxico das respectivas línguas. Assim sendo, as unidades linguísticas aportuguesadas serão consideradas estritamente no contexto do português.

Por outro lado, convém ter-se em consideração que não apenas os topônimos africanos são aportuguesados ao integrarem o léxico da LP. Como se pode constatar, topônimos como França, Estados Unidos da América, Nova Iorque e Inglaterra obedecem a diferentes processos de integração no léxico da LP. Com efeito, em França (de France) observa-se o fenômeno de adaptação, em Estados Unidos da América (de The United States of America) observa-se o fenômeno de decalque, e em Nova Iorque (de New 
York) e Inglaterra (de England) observa-se simultaneamente os fenômenos de decalque e adaptação.

A diferença entre os casos acima evocados e os que acontecem em Angola é que nos exemplos apresentados há um afastamento geográfico entre os diferentes sistemas linguísticos, contrariamente ao que sucede em Angola, onde a LP e as LA coexistem no mesmo espaço, o que gera alguma resistência na aceitação desses fenômenos.

\section{Consoantes}

O fonema $/ \mathrm{k} /$ deve ser representado na escrita da seguinte forma:

- pelo grafema $<\mathrm{c}>$, quando seguido das vogais /a/, /o/ ou /u/ Camissombo, Camilungo, Camibafo, etc.

- pelo grafema <qu>, quando seguido de /e/ ou /i/ - Quiala, Quínguila, Quemba.

O fonema /g/ deve ser representado da seguinte maneira:

- pelo grafema $<\mathrm{g}>$, quando seguido da vogal /a/, /o/ ou /u/ Cangambo, Cangando, Quingungo.

- pelo grupo <gu>, quando seguido de /e/ ou /i/ - Quínguila.

O fonema /s / deve ser representado na escrita do seguinte modo:

- pelo grafema $<\mathrm{s}>$, em início de palavra;

- pelo grafema $<$ ss $>$, entre vogais - Camissombo, Cassembele, Quissama.

O fonema $/ z /$ deve ser escrito sempre com $<z>-$ Caminzaje, Quizela, Cajimbenza.

O fonema $/ 3 /$ deve ser representado graficamente por $<j>$, nunca por $\left\langle\mathrm{g}>-\right.$ Malanje, ${ }^{8}$ Cajimbinza, Cajimbenza, Camueje.

\footnotetext{
${ }^{8}$ A ocorrência da sílaba je depois de vogal $+\mathrm{n}(a n, e n, i n, o n, u n)$ é pouco frequente em Português, sobretudo em nomes. Em palavras como laranjeira e enjeitar, por exemplo, a ocorrência da sílaba je deve-se ao fato de $\mathbf{j}$ existir na palavra primitiva. Ocorre também em palavras como conjectura. Em final de palavra, porém, ocorre em certas formas verbais como esbanje (de esbanjar). Em contrapartida, a sílaba ge parece ser mais frequente em nomes como, por exemplo, falange, alfange, flange, e em verbos como abrange, constrange, tange etc.
} 
O fonema $/ \mathrm{J} /$ deve ser representado na grafia unicamente por $<\mathrm{x}>$ - Cambaxe, Maxinde, Camissoxe.

O fonema $/ \mathrm{n} /$ deve ser representado por $<$ nh $>$ - Quimonha.

O fonema / h/ desaparece, todavia, na escrita, o grafema $<\mathrm{h}>$ permanece - Cahunje, Caluhia, Muhemba, Camahaxe.Sempre que a consoante inicial for precedida de som nasal $(/ \mathrm{mb} /, / \mathrm{nd} /, / \mathrm{gg} /, / \mathrm{nj} /$, $/ \mathrm{mv} /, / \mathrm{nz} /$ ), a grafia aportuguesada deve obedecer aos seguintes critérios:

- $<\mathrm{mb}>\mathrm{e}<\mathrm{mv}>$ perdem nasalidade, ou seja, passam a consoantes orais.

- <nd, ng, nj> e <nz $>$ separam-se e passam a formar sílabas separadas - N'deia, N'gola Luíje, N'zumba-ia-N'ganga, N'guvo.

Todavia, quando os referidos fonemas ocorrem no interior da palavra, a nasalidade reverte-se para a vogal precedente, sendo que só se grafará $<\mathrm{m}>$ antes de $<\mathrm{b}>$ ou $<\mathrm{p}>-$ N'gumba, Quingungo, Cahunje, Caminzaje, Candende.

\section{Vogais}

As vogais apresentam o mesmo valor que em Português, salvo nos seguintes casos:

A vogal /i/ em final de palavra deverá escrever-se $<\mathrm{e}>-$ Malanje, N'gola Luíje, Cahunje, Caminzaje. Em alternativa, poderá manter-se o grafema $<\mathrm{i}>$, recorrendo-se à acentuação da vogal da penúltima sílaba, no caso das palavras paroxítonas - Malânji, N’gola Luíji, Cahúnji, Caminzáji.

A vogal /u/ em final de palavra escrever-se-á $<_{0}>-$ Cangambo, Candendo, N'dungo, Camibafo. Tal como no caso anterior, em alternativa, poderá manter-se o grafema $<\mathrm{u}>$, acentuando-se, no caso das palavras paroxítonas, a vogal da penúltima sílaba - Cangâmbu, Candêndu, N'dúngu, Camibáfu.

As sequências de vogais deverão formar ditongos ou hiatos, como acontece na LP - Camueia, N'deia, Quiala, Caiala.

\footnotetext{
${ }^{9} \mathrm{Se}$, porém, o uso não tiver consagrado a desnasalização da consoante pré-nasal, julga-se razoável escrever tais consoantes como o uso as consagra.
} 


\subsection{Critério de escrita segundo as LA}

No que diz respeito à grafia segundo as LA, neste caso o Kimbundu, o critério a seguir deve refletir, obviamente, as particularidades fonológicas da língua de origem do topônimo. Nesses casos, o modelo a adotar (enquanto não se criam novas regras de escrita) deverá estar em consonância com o alfabeto usado pelo ILN, baseado na Resolução n ${ }^{\circ} 3 / 87$, de 23 de maio de 1987. O princípio adotado para o alfabeto das LA é de que cada grafema corresponda a um fonema. No caso do Kimbundu, são exceção ao referido princípio os dígrafos $<\mathrm{mb}$, nd, ng, nj, mv, nz, ny, bh $>$ e $<$ th $>$, correspondendo cada dígrafo a um fonema. Assim sendo, teremos os seguintes critérios:

\section{Consoantes}

As consoantes /b/, /d/, /f/, /h/, /l/, /m/, /n/, /p/, /t/, /v/ e $/ \mathrm{z} /$ serão representadas graficamente por $<\mathrm{b}, \mathrm{d}, \mathrm{f}, \mathrm{h}, \mathrm{l}, \mathrm{m}, \mathrm{n}, \mathrm{p}, \mathrm{t}, \mathrm{v}>\mathrm{e}<\mathrm{z}>$, respectivamente - Kamibafu, Dimba, Fumba, Kahunji, Luma, Kamembe, Kanambwa, Pata, Tuma, Vamvala, Kamizalela.

As consoantes $/ \mathrm{nd} /, / \mathrm{mb} /, / \mathrm{mv} /, / \mathrm{nz} /$ devem ser representadas graficamente por $<\mathrm{nd}, \mathrm{mb}, \mathrm{mv}, \mathrm{nz}>$, respectivamente-Ndungu, Kandende, Kandendu, Kangambu, Kamembe, Vamvala de Cima, Kaminzaji, Kajimbenza.

A consoante $/ \mathrm{gg} /$ será representada por $<$ ng $>$. O grafema $<\mathrm{g}>$ nunca ocorrerá isoladamente - Nguvu, Ngola Lwiji, Kingungu.

A consoante /s/ deve ser representada, na escrita, exclusivamente pelo grafema $<$ s $>$. O grafema $<$ s $>$ nunca ocorrerá dobrado (ss) - Kasembele, Kasekele, Kasembala.

As consoantes $/ 3 /$ e $/ \mathrm{n} 3 /$ serão representadas graficamente por $<\mathrm{j}>$ e $<$ nj $>$ - Ngola Lwiji, Kamweji, Kajimbenza, Kajimbinza, Kasanji Kalowama, Kisanji, Kahunji.

A consoante $/ \mathrm{J} /$ será representada pelo grafema $<\mathrm{x}>-$ Kambaxi, Kamahaxi, Maxinde.

A consoante $/ \mathrm{n} /$ será representada pelo dígrafo $<$ ny $>$ - Kimonya. 


\section{Vogais}

As vogais do Kimbundu, como já dissemos no segundo capítulo, são similares às do Português, sendo todas orais. As particularidades são as seguintes:

O grafema $<_{\mathrm{O}}>$ em final de palavra corresponde ao fonema /o/ Mukongo, Pombo, Kambombo.

O grafema $\langle\mathrm{e}\rangle$ em final de palavra corresponde ao fonema /e/ Kandende, Kasekele, Kamembe, Kasembele.

O fonema / $\mathrm{u} /$ é representado graficamente apenas por $<\mathrm{u}>-$ Kangambu, Kandumbu, Kula Muxitu.

Sempre que os fonemas /i/ e / $\mathrm{u} /$ ocorrem junto de outra vogal, sendo semivogais $(/ \mathrm{j} /, / \mathrm{w} /)$, são representados graficamente por $\langle y>$ e $<w>$, respectivamente - Kayala, Kanambwa, Kamweji.

Há, entretanto, casos que precisam ser estudados de forma mais aprofundada. Por exemplo, discute-se como se deverá grafar, em Kimbundu, o topônimo Luanda: Amélia Mingas (2000) grafa Lwanda, o que sugere que a semivogal /w/ é breve; já Arsénio, Sebastião e Adão (2013), no Manual de Alfabetização em Kimbundu, editado pelo Ministério da Educação, grafam Luwanda, pressupondo que há uma vogal / $\mathrm{u}$ / longa. Essa variação na escrita de certos topônimos depende muito da percepção da duração do som vocálico, o que acontece sobretudo quando as vogais /i/ e /u/ são seguidas de outro som vocálico, como em Quiala: Kyala ou Kiyala?

Outro aspecto que joga em desfavor de uma grafia segundo as LA é o fato de a grande maioria dos falantes não conhecer as regras de ortografia das mesmas, não só devido ao elevado nível de analfabetismo, mas principalmente por haver um défice no ensino destas, pois atualmente é necessário ter uma formação universitária (particularmente no domínio da linguística) para se ter um domínio das regras ortográficas das LA. Por isso, corrobora-se a afirmação de Coelho (1999, p. 45), segundo a qual "[p] arece chegado o tempo dos lexicógrafos angolanos se porem de acordo, abandonarem trincheiras e encararem soluções no sentido de se unificar a ortografia". 


\section{Considerações finais}

Este trabalho começou por discorrer sobre determinados conceitos que dão base à investigação. Desse modo, viu-se que o estudo dos topônimos não se restringe apenas à linguística, dado que a toponímia também é objeto de estudo da cartografia, da geografia ou da topografia. À linguística interessa sobretudo a estrutura morfológica do topônimo, sua significação e os processos fonéticos que se dão na evolução do topônimo ao longo do tempo.

O estudo da toponímia permite compreender os valores culturais, mitos e crenças de um determinado povo, a fauna, a flora, o relevo e a hidrografia de um determinado lugar. Procurou-se igualmente apresentar uma classificação dos topônimos, tendo como base os seus significados.

Quanto aos topônimos propriamente ditos, verificou-se que na área urbana de Malanje predominam os topônimos de LP, enquanto nas áreas suburbana e rural prevalecem os topônimos de origem Kimbundu. Do ponto de vista da estrutura morfológica, notou-se que determinados topônimos de origem Kimbundu, formados por derivação, apresentam uma combinação de prefixos pouco frequente em palavras da língua corrente, dado que juntam prefixos singulares a nomes plurais.

Do ponto de vista gráfico, focámo-nos sobretudo nos topônimos de origem Kimbundu, uma vez que são estes que muitas vezes apresentam variações gráficas. Nesse aspecto, considerou-se que os topônimos aportuguesados são palavras que integram o léxico do português de Angola, pelo que não devem ser confundidos com os seus equivalentes vernáculos do Kimbundu. Por esse fato, julga-se não fazer sentido a afirmação de que os topônimos aportuguesados são uma deturpação da ortografia e fonologia das LA.

\section{Referências}

ADMINISTRAÇÃO MUNICIPAL DE MALANJE. Perfil municipal de Malanje. Malanje: AMM, 2012.

ANGOLA. Lei no 17/16, de 7 de outubro de 2016 - Lei de bases do sistema de educação e ensino. Diário da República. 7 out. 2016. I Série. nº 170.

ANGOLA. Lei no 14/16, de 12 de setembro de 2016 - Lei de bases da toponímia. Diário da República. 12 set. 2016. I Série nº 155. 
ANGOLA. Constituição da República de Angola. Diário da República. 5 fev. 2010. I Série. $\mathrm{n}^{\circ} 23$.

ANGOLA. Resolução n 3/87, de 23 de maio de 1987. Diário da República. 23 maio 1987. I Série. $n^{\circ} 41$.

ARSÉNIO, M. J.; SEBASTIÃO, J. J. C.; ADÃO, A. Manual de alfabetização em kimbundu. Luanda: Ministério da Educação, 2013.

AZEREDO, J. C. Gramática Houaiss da língua portuguesa. 3. ed. São Paulo: Publifolha, 2012.

CASTIGLIONI, A. C.; BARROS, L. A.; ISQUERDO, A. N. Um olhar sobre a toponímia dos rios em Mato Grosso do Sul. Antares: Letras e Humanidades, Caxias do Sul, v. 4, n. 8, p. 146-157, jul./dez. 2012.

CASTRO, I. Ortografia portuguesa. In: SELECÇÕES do Reader's Digest. Falar melhor, escrever melhor. Lisboa: Selecções do Reader's Digest, 1991.

CHIVINGA, A. N. Que futuro para as linguas nacionais angolanas? Ensaio sobre as políticas de protecção e valorização das línguas nacionais angolanas. Luanda: Centr'Artes, 2014

COELHO, S. Angola: histórias e estórias da informação. Luanda: Executive Center, 1999. COSERIU, E. A perspectiva funcional do léxico. In: . Problemas da lexicologia e lexicografia. Porto: Livraria Civilização Editora, 1979.

COSTA, A. F. Rupturas estruturais do português e linguas bantu em Angola: para uma análise diferencial. Luanda: UCAN, 2006.

COSTA, R. Corpus de spécialité: une question de types ou de genres de textes ou de discours. In: BENJOIT, H; MANIEZ, F. (ed.). De la mesure dans les termes: hommage à Philippe Thoiron. Lyon: Presses Universitaires de Lyon, 2005. p. 313-324

DICK, M. V. P. A. Atlas toponímico do Brasil: teoria e prática II. Revista Trama, Marechal Cândido Rondon, PR, v. 3, n. 5, p. 141-155, 2007.

DICK, M. V. P. A. Fundamentos teóricos da toponímia. Estudo de caso: o Projeto ATEMIG - Atlas Toponímico do Estado de Minas Gerais (variante regional do Atlas Toponímico do Brasil). In: SEABRA, M. C. T. C. (org.). O léxico em estudo. Belo Horizonte: Faculdade de Letras da UFMG, 2006. p. 91-117.

DICK, M. V. P. A. A dinâmica dos nomes na cidade de São Paulo 1554-1897. São Paulo: Annablume, 1996.

DICK, M. V. P. A. Toponímia e cultura. Revista do Instituto de Estudos Brasileiro, São Paulo, n. 27, p. 93-101, 1987. 
FERNANDES, J.; NTONDO, Z. Angola: povos e línguas. Luanda: Nzila, 2002.

GRANDE enciclopédia portuguesa e brasileira. Lisboa; Rio de Janeiro: Editorial Enciclopédia, 1968. v. 32. p. 70-84.

GUIRAUD, P. A semântica. 5. ed. Rio de Janeiro: Bertrand, 1989.

INSTITUTO NACIONAL DE ESTATÍSTICA. Resultados definitivos do recenseamento geral da população e habitação de Angola 2014. Luanda: INE, 2016.

INSTITUTO NACIONAL DE ESTATÍSTICA. Resultados preliminares do recenseamento geral da população e habitação de Angola 2014. Luanda: INE, 2014.

KIRKNESS, A. Sobre a lexicografia e lexicografia das palavras estrangeiras. In: VILELA, M. (Trad. e intr.). Problemas da lexicologia e lexicografia. Porto: Livraria Civilização Editora, 1979. p. 225-241

MATEUS, M. H. M. et al. Fonética, fonologia e morfologia do português. Lisboa: Universidade Aberta, 1990.

MINGAS, A. Interferência do Kimbundu no português falado em Lwanda. Luanda: Chá de Caxinde, 2000.

QUINTÃO, J. L. Gramática de Kimbundo. Lisboa: Edições Descobrimento, 1934.

RAPOSO, E. B. P. et al. (org.). Gramática do português. Coimbra: FCG, 2013. v. 1.

RASTIER, F. Enjeux épistémologiques de la linguistique de corpus. In: WILLIAMS, G. (dir.). La linguistique de corpus. Rennes: Presses Universitaires de Rennes, 2005.

REIS, V. Sociolinguistica: dinâmica funcional vs problemas funcionais da língua. Luanda: Nzila, 2006.

SANTOS, E. S. A cidade de Malanje na história de Angola (dos finais do século XIX até 1975). Luanda: Nzila, 2005.

SEABRA, M. C. T. C. A formação e a fixação da língua portuguesa em Minas Gerais: a toponímia da região do Carmo. 2004. 368f. Tese (Doutorado em Linguística) - Faculdade de Letras da UFMG, Belo Horizonte, 2004.

SEERMANN, J. A toponímia como construção histórico-cultural: o exemplo dos municípios do estado do Ceará. Vivência: Revista da Antropologia, Natal, n. 29, p. 207-224, 2005. 
SILVA, M. W. P.; OLIVEIRA, M. O. E. O Bibliotecário Pesquisador: um estudo com topônimos transplantados. Múltiplos Olhares em Ciência da Informação, Belo Horizonte, v. 2, n. 2, p. 1-11, out. 2012. Disponível em: https://periodicos.ufmg.br/index.php/moci/article/view/16965/13727. Acesso em: 20 dezembro 2014

TAVARES, M. C.; ISQUERDO, A. N. A questão da estrutura morfológica dos topônimos: um estudo na toponímia sul-mato-grossense. Signum: Estudos da Linguagem. Londrina, v. 9, n. 2, p. 273-288, dez. 2006. DOI: https://doi. org/10.5433/2237-4876.2006v9n2p273. Disponível em: http://www.uel.br/ revistas/uel/index.php/signum/article/view/3956. Acesso em: 7 maio 2014.

TOPÔNIMOS africanos devem ser escritos de acordo com a grafia bantu. Semanário Angolense, Luanda, ano X, ed. 583, p. 22-25, 20 set. 2014.

ULLMANN, S. Semântica: uma introdução à ciência do significado. 4. ed. Lisboa: FCG, 1977.

VASCONCELLOS, J. L. Opúsculos. Coimbra: Imprensa da Universidade, 1931. v. 3.

VILELA, M. Estudos de lexicologia do português. Coimbra: Almedina, 1994.

VILLALVA, A. Morfologia do português. Lisboa: Universidade Aberta, 2008.

ZAU, F. Angola: trilhos para o desenvolvimento. Lisboa: Universidade Aberta, 2002.

Data de recebimento: 23/01/2020. Data de aprovação: 28/08/2020. 